\title{
Determinants of Quality Services Provision of Local Government: Evidence from Bangladesh
}

\author{
Musfiqa Ashraf \\ Bangladesh Open University, Bangladesh \\ Dr. Mohammad Moniruzzaman \\ International Islamic University Malaysia (IIUM), Malaysia \\ Dr. S. M. Abdul Quddus \\ International Islamic University Malaysia (IIUM), Malaysia
}

Received: May 13, 2018 Accepted: June 12, 2018 Online published: June 28, 2018

doi:10.5296/jpag.v8i2.13131 URL: https://doi.org/10.5296/jpag.v8i2.13131

\begin{abstract}
The present study aimed at exploring the determinants of perceived quality services of Dhaka City Corporation (DCC) provided towards the slum dwellers. For the purpose of the study, data were collected from the respondents with a structured questionnaire survey using stratified random sampling. Collected data were analysed using partial least squares (PLS) with the support of the software Smart PLS 2.0 M3. The statistical findings of this study reveal that tangibility, responsiveness, reliability, empathy dimensions and logistic supports are the significant factors influencing the perceived service quality services of the local government. Among them, responsiveness was found to the most significant followed by logistic support, empathy, reliability and tangibles. The outcome of this research work has enriched the existing body of knowledge in the field of local government's service quality. The policy makers, local government and other related stakeholders might find this study as an essential tool in designing, developing and implementing their activities directed to the slum dwellers.
\end{abstract}

Keywords: service quality and local government

\section{Introduction}

Dhaka City is one the most populated cities in the world. Dhaka, the capital city of 
Bangladesh, is the eleventh largest megacity in the world, with a population of 18.3 million people living in an area of $1528 \mathrm{~km} 2$ (Dhaka City Corporation, 2017). Approximately 300,000 to 400,000 new poor migrants enter the capital every year (Bangladesh Bureau of Statistics, 2016). Since 1972, a massive growth has been noticed in the expansion of the Dhaka city immediately after its transformation from a provincial capital into a national capital of newly independent country, Bangladesh. At present, 35 percent of the total urban population of Bangladesh live in Dhaka city; on the other hand, around 60 percent urban population is hosted by other major cities like Chittagong, Rajshahi, Sylhet, and Khulna (BBS, 2017). Consequently, around 18.3 million people are living in Dhaka city and it is projected that by 2020, the population of this city will be around 20 million. The city is, however, increasingly characterized by large slums, poor housing, traffic congestion, water shortages, poor sanitation and drainage, irregular electric supply, unplanned construction, increasing air pollution and poor urban governance which result in growing problems of law and order (Akter et al., 2015; Baker, 2007). The Dhaka City Corporation (DCC) is the authority to serve the people of this mega city. Dhaka City Corporation (DCC) is responsible for providing some of the basic amenities to its citizen with its limited resources. As the authority, DCC needs to ensure a healthy and clean city. However, previous studies evidenced that DCC failed to provide adequate services to its citizens (Hossain et al., 2004; Islam \& Shafi, 2004; Alam, 2005; Luck, 2008).

The local government in the Dhaka city is the Dhaka City Corporation. They are responsible for the overall management of the basic services the city dwellers deserve from the government. Very few studies have been conducted regarding the assessment of services provided by the local government in the context of DCC. Suraiya and Imranur (2017) did a review research to summarize the recent year's state of waste generation and management practices. The review reveals that he waste management practice is not very satisfactory and needs adequate policy and awareness. Islam (2016) in his study highlighted the problems and prospects of solid waste management in Dhaka city. Siddiqui (2017) conducted a study to find out the major challenges that the urban environment has been facing in sustainable development in Dhaka city. Lack of swamp, open places, public parks, land with tree cover up causes environmental degradation and also creates aesthetic discomfort is another challenge in urban areas. Kabir (2016), in his paper mentioned that urban local bodies all over the world are facing challenges in meeting citizens' needs. Aziz (2012) tried to investigate the water supply services provided by DCC. The findings regarding drinking water supply suggest that majority of the Dhaka dwellers are fully or to an extent largely satisfied with the water supply. Jahan et al., (2015) conducted a study to assess the socioeconomic status of the urban slum population of the Dhaka city. They found that the conditions of slums, including sanitation and water supply, has to some extant improved in the recent years. Swapon et al., (2017) have tried to trace the growth of a megacity and its informal urbanization process in Dhaka. Their study reveals that the main reason for the problem is unplanned expansion of the city caused by overwhelming population which is continuously creating pressures on the limited infrastructures of the city. Akter et al., (2009) conducted a study to measure the performance of waste management, mosquito control and certification service offered by Dhaka City Corporation in some selected wards of Dhaka City. 
The study concluded that citizen of Dhaka ranked the waste management and certification service as fair while mosquito control service was identified as poor. Therefore, the above discussion shows that there are some studies on the services of DCC but those are conducted on a particular service like waste management, water supply and so on. The findings also reveal that city dwellers in most of the cases are not satisfied at the services of DCC. On the other hand, there is hardly any study conducted on the determinants of quality services of DCC from the slum dwellers' perspective. Based on this ground, the present study aimed at exploring the determinants of perceived quality services of Dhaka City Corporation (DCC) towards the slum dwellers.

\section{Perceived Quality Services Provision of Local Government and the Servqual Model}

Service quality is characterized as the result of the correlation that customers make the desires between a service and perception of the method when the service was conveyed (Bolton \& Drew, 2005). The service providers should frequently assess the service quality given to their customers in order to enhance their service, recognizing issues rapidly, and better evaluating the customer fulfilment (Patterson and Spreng, 1997). Two of the most widely concepts on service quality that is acknowledged and utilized by researchers is the SERVQUAL model by Parasuraman et al., (1988) and the functional quality structure by Gronroos (1983, 1990). Parasuraman et al., (1985), prescribed an applied system of service quality based on the interpretation of subjective information from wide logical examination. Parasuraman et al., (1988) just viewed as five dimensions in their appraisal of service which comprised of reliability, responsiveness, assurance, empathy, and tangibles. These five dimensions indicate how the customers manage information on service quality (Cook \& Verma, 2002). Various studies, guided by SERVQUAL model were conducted to assess on the quality of services in public administration (Donnelly \& Shiu, 1999; Wisniewski, 2001; Brysland \& Curry, 2001; Rodriguez et al., 2009; Van Ryzin, 2004). Brysland and Curry (2001) stated that the literature clearly supported the use of SERVQUAL in public sector. Using SERVQUAL model, Ramseook et al., (2010) also measured employees and customer perceptions of service quality in public service in Mauritius. Selvakumar (2016) also conducted a study for measuring customer satisfaction within the public sector and private bank sector in India. Thus, this study uses SERVQUAL model in order to investigate the influence of its dimensions on the perceived quality services of local government provided towards the slum dwellers in Dhaka city. However, this study will augment one more substantial factor into the conceptual framework; logistic support. Based on the DCC functions and service provision to slum dwellers, this logistic support is very essential when it comes to delivering quality service. The next section discusses these dimensions in relation to quality services of local government.

\subsection{Tangibility}

Tangible dimension means the appearance of physical facilities, equipment, personnel and communication materials (Parasuraman et al, 1985). The tangibility dimension shows that the physical aspects enhance the physical facilities, staffs' appearance and equipment utilized for the procurement of services. Tangibility dimension is imperative for service provider (Atalik 
\& Arslan, 2009) particularly on communication safety and adequacy of services. All resources have to be allotted with the most elevated monetary. Some service firms have acquainted service activities with better support to their customers (Ishikawa, 1996). This demonstrated that service quality in the service business is a significant performance indicator to figure out whether the quality management system and tangibility implementation is sufficient (Kim, 2004). Numerous organizations considered that quality of service on view of customers is a good indicator of the quality of performance in organization. Tangibility is a critical performance indicator of service quality to determine whether the quality management system and tangibility implementation is adequate (Kim, 2004). For giving the maximum satisfaction, the tangibility dimension of service quality is a must and previous researchers found that there is a positive relationship between the tangibility dimension and performance outcome (Atalik, Arslan \&Ahamad, 2009; Munhurrun, Bhiwajee \&Naidoo, 2010; Wanjiru, 2013). Therefore, the present study hypothesizes that;

H1: Tangibility is positively and significantly correlated with perceived quality service provision.

\subsection{Responsiveness}

Responsiveness refers to the willingness to help customers and give quick services (Parasuraman et al., 1985). Responsiveness dimension of service quality indicates how fast the staffs are willing to provide services to the customers. Tahir and Bakar (2007) found in their study that responsiveness one of the most important dimensions for providing good quality services. The researchers also found that there is a positive relationship between responsiveness and good performance outcomes (Ahamad, 2009; Wanjiru, 2013). Customers evaluate the responsiveness of organizations by tracking the amount of time taken by them to respond to customers' orders, request or any other types of queries. Responsiveness dimension shows staff ready to provide services rapidly to the customers. Tahir and Abu Bakar (2007) analysed the service quality and customer satisfaction by using SERVQUAL in Malaysia and indicated that responsiveness shows as the most imperative measurement of service quality. Responsiveness is the promptness and the degree to which the local government authority can address problems of slum dwellers. Since, the slum dwellers live in miserable situations, an increased emphasis on availability of all necessary services may increase the perceived quality services of slum dwellers. If responsiveness in the services of local government increases, it obviously brings quick benefits for the slum dwellers. Therefore, it is hypothesized that;

H2: Responsiveness is positively and significantly correlated with perceived quality service provision.

\subsection{Reliability}

Reliability means as the ability to provide the promised service dependably and accurately (Parasuraman et al., 1985). It also comprises of "promises" and "doing it right" sub-dimensions. Customers always expect that the service providers provide services on time and in a well-mannered way without any errors. Therefore, employees should provide perfect 
services to the customers to satisfy them in a better way. Reliability also means the ability to perform the services constantly and precisely in a steady manner (Zeithaml; et al, 2006). Atalik and Arslan (2009) suggested that reliable service is the result of the continuous improvement. Busterna (1998) asserted that service reliability is the service centre to most customers. Some of the researchers found that there is a positive relationship between the reliability dimension and performance outcomes (Parasuraman, 1988; Berry \& Parasuraman, 1991; Ahamad, 2010; Chang \& Wang, 2011; Wanjiru, 2013).Hence it is hypothesized that;

H3: Reliability is positively and significantly correlated with perceived quality service provision.

\subsection{Assurance}

Assurance is another important dimension of SERVQUAL model. It refers to the knowledge and courtesy of employees and their capacity to encourage trust and confidence (Parasuraman et al., 1985). Courtesy involves politeness, respect, consideration, and friendliness of contact personnel to give better services. Similarly, local government should give assurance that they are committed to providing quality services to the citizens. It is examined that correspondence and stimulation organizations built up the customer satisfaction by guaranteeing the reliable behaviour and impression of genuine duties to the service provision (Nelson \& Chan, 2005). Fornell and Wernerfelt (1997) and Arasli et al.(2005) attested that the assurance dimension of service quality has the most grounded effect on customer satisfaction that leads to positive relationship in order to improve the performance. This indicates that service quality will be improved when there is an improvement of assurance. Some of the researchers found that there is a positive association between the assurance dimension and quality service (Arasli, 2005; Cavana et al., 2007; Munhurrun, Bhiwajee \& Naidoom 2010; Wanjiru, 2013). Therefore, service providers should always have a good blending of instruments for making sure that they are capable of providing better services. From that ground it is hypothesized in this study that;

H4: Assurance positively influences perceived quality service provision.

\subsection{Empathy}

Empathy is defined as caring, individualized attention the firm provides its customers. It also includes access to organization's representatives, communication and understanding. This empathy dimension shows the measurement of caring and individual consideration given to the slum dwellers. Individual consideration is fundamental for the better performance because of inflexible rivalry. Customers view empathy as a vital measurement of service quality (Jabnoun \& Al Tamimi, 2003). It is suggested that employee's commitment to convey quality services, handling of conflicts with skill completely and conveyance of services proficient and will bring about customer satisfaction for long haul advantages (Nelson \& Chan, 2005). For this reason, local government staff should be empathetic while serving the slum dwellers so that perceived quality services can be improved. Wanjiru (2013) investigated that a unit increment in the empathy will lead to the increment in the scores of the performance in the organization.Hollis\& Victor (2004) examined that the empathy of service quality is important 
to the firm performance. Ahamad (2009) demonstrated that the empathy of the service quality has positive relationship to the customer satisfaction which will improve the organizational performance in the company. Hence the following hypothesis is developed:

Hypothesis 5: Empathy positively influences perceived quality service provision.

\subsection{Logistic Support}

For providing better services to the slum dwellers, Dhaka City Corporation should have enough logistic support that encompasses the logistic services, materiel, and transportation required to support the continuous development work in the slums. Proper logistic support might enable the workforce to provide better services. Generally, logistic support refers to activities that support local government (the service authority) to fulfil its responsibilities (Jarosław, 2013). To be effective, logistic support to local government requires a strong strategy that recognizes diverse capacity needs, includes a dedicated budget for institutional support, and provides for capacity building and training (Julia, 2015). The local government should have all the logistics support that provides facilities, services, resources and other support services for the smooth operations of its activities. The logistic support department should ensure that the logistics function is carried out in support of the authority (Nowak, 2009). The DCC should establish the appropriate level of unit staffing within the logistics section, continuously monitoring the effectiveness of the organization and modifying as required. Proper logistic support might enable the workforce to provide better services. Based on the above discussion, this study hypothesizes that;

Hypothesis 6: Logistic support positively influences perceived quality service provision

\section{Research Methodology}

The present study has six independent variables and one dependent variable. Items for five variables related to the dimensions of service quality have been adapted from the study conducted by Sandhu and Nagpal (2011) who had used this scale in their research and the internal consistency was more than 0.70 for all the constructs. For this reason the present study adapted the items for service quality dimensions from Sandhu and Nagpal (2011). The items for another independent variable namely logistic support has been self-developed. The items were measured with 5 point Likert scale with response options ranging from strongly agree (5) to strongly disagree (1). After the pilot study, data were collected from 222 slum dwellers living in the six big slums which are Shampur, Tejgaon, Bhasantak, Korail, Kamalapur and Zurain slums to examine the relationship between the independent and dependent variables. The data of this study were collected from the respondents with a structured questionnaire survey. The method of selecting the respondents in each slum was the stratified random sampling. Partial least squares structural equation modelling (PLS-SEM) with the support of the software Smart PLS 2.0 M3 was employed to analyse the collected data (Ringle et al., 2005). There are models in PLS SEM analysis. The first measurement mode gives the values for reliability and validity of data while the structural model (second) output is used for testing the hypotheses.

This PLS SEM is the second-generation multivariate statistical analysis and researchers all 
over the world are using this technique for its suitability in various areas (Murillo-Luna et al., 2011; Pereira-Moliner et al., 2012). PLS was used in this study as it is the most appropriate method of data analysis for small sample size (Qureshi \& Compeau, 2009). The present study chose PLS-SEM as the data analysis technique since it has several relationships between the exogenous and endogenous variables. The findings of measurement and structural models are presented below.

\section{PLS-SEM Analysis Results}

In Partial Least Square Structural Equation Modelling (PLS-SEM) analysis, the PLS measurement model gives the values of reliability test, validity test and path coefficient along with the coefficient of determination. The present study has six exogenous variables and one endogenous variable. The findings of measurement model are also documented in table 4.1.

\subsection{Reliability Test}

The first step is to assess the reliability and validity of the constructs in the measurement model (outer model).Reliability refers to the internal consistency of data (Hair et al., 2014).Cronbach's alpha and Composite reliability values are used to assess reliability of constructs. For reliability, all constructs should have Cronbach's alpha values above the threshold of 0.70 (Hair et al. 2012)' and the composite reliability values of the all constructs should be greater than the threshold of 0.70 (Bagozzi\& Yi, 1988). As shown in table 4.1, all the Cronbach alpha and composite reliability values are above 0.70 which indicates good internal consistency of data (Hair et al., 2012) and the reliability of all constructs are established in this study.

Table 4.4. Measurement Properties of Constructs.

\begin{tabular}{|c|c|c|c|c|c|}
\hline Variables & Items & Loadings & $\begin{array}{l}\text { Cronbach } \\
\text { alpha }\end{array}$ & $\begin{array}{l}\text { Composite } \\
\text { Reliability }\end{array}$ & $\begin{array}{l}\text { Average } \\
\text { Variance } \\
\text { Extracted(AVE) }\end{array}$ \\
\hline \multirow{4}{*}{ Tangibility } & T1 & 0.610 & \multirow{4}{*}{0.769} & \multirow{4}{*}{0.837} & \multirow{4}{*}{0.568} \\
\hline & $\mathrm{T} 2$ & 0.925 & & & \\
\hline & T3 & 0.766 & & & \\
\hline & $\mathrm{T} 4$ & 0.668 & & & \\
\hline \multirow{5}{*}{ Reliability } & R1 & 0.962 & \multirow{5}{*}{0.907} & \multirow{5}{*}{0.894} & \multirow{5}{*}{0.636} \\
\hline & R2 & 0.684 & & & \\
\hline & R3 & 0.955 & & & \\
\hline & $\mathrm{R} 4$ & 0.645 & & & \\
\hline & R5 & 0.645 & & & \\
\hline \multirow{4}{*}{ Responsiveness } & RS1 & 0.516 & \multirow{4}{*}{0.812} & \multirow{4}{*}{0.876} & \multirow{4}{*}{0.651} \\
\hline & RS2 & 0.865 & & & \\
\hline & RS3 & 0.871 & & & \\
\hline & RS4 & 0.914 & & & \\
\hline \multirow{4}{*}{ Assurance } & A1 & 0.829 & \multirow{4}{*}{0.859} & \multirow{4}{*}{0.904} & \multirow{4}{*}{0.703} \\
\hline & A2 & 0.845 & & & \\
\hline & A3 & 0.832 & & & \\
\hline & A4 & 0.849 & & & \\
\hline \multirow{3}{*}{ Empathy } & E1 & 0.609 & \multirow{3}{*}{0.819} & \multirow{3}{*}{0.857} & \multirow{3}{*}{0.548} \\
\hline & E2 & 0.638 & & & \\
\hline & E3 & 0.793 & & & \\
\hline
\end{tabular}




\begin{tabular}{|c|c|c|c|c|c|}
\hline & $\mathrm{E} 4$ & 0.889 & & & \\
\hline & E5 & 0.715 & & & \\
\hline \multirow{5}{*}{ Logistic Support } & L1 & 0.942 & \multirow{5}{*}{0.869} & \multirow{5}{*}{0.905} & \multirow{5}{*}{0.666} \\
\hline & L2 & 0.586 & & & \\
\hline & L3 & 0.932 & & & \\
\hline & L4 & 0.588 & & & \\
\hline & L5 & 0.938 & & & \\
\hline \multirow{4}{*}{$\begin{array}{l}\text { Perceived Quality Service } \\
\text { Provision }\end{array}$} & QSP1 & 0.936 & \multirow{4}{*}{0.913} & \multirow{4}{*}{0.943} & \multirow{4}{*}{0.810} \\
\hline & QSP2 & 0.757 & & & \\
\hline & QSP3 & 0.925 & & & \\
\hline & QSP4 & 0.929 & & & \\
\hline
\end{tabular}

\subsection{Convergent Validity}

Convergent validity is interpreted as the extent to which indicators actually represent the intended latent variables and indeed correlate with other indicators of the same latent variable (Hair, et al., 2007). Construct's average variance extracted (AVE) and factor loadings are used for assessing the convergent validity. If the constructs have an average variance extracted (AVE) value higher than 0.50, it means that convergent validity is established (Fornell and Larcker, 1981). As shown in table 4.1, all the values of AVEs are above 0.50 which confirms the convergent validity of constructs. The absolute standardized outer loadings of items are above 0.50. Chin (1998) believes that loadings over 0.5 still be acceptable if there exists other indicators in the block for comparison. Table 4.1 shows that all the item loadings are higher than 0.50 ; and also the items are significant which confirms convergent validity at indicator level. Therefore, 0.50 and above AVE values of all the constructs and 0.50 and above values of item loading confirm the convergent validity of constructs in this study.

\subsection{Discriminant Validity}

Discriminant validity refers to the extent to which a particular latent construct is different from other latent constructs (Duarte Raposo, 2010).Discriminant validity is established when the indicators loadings on their measured construct are all greater than the cross-loadings on other constructs and the square root of each construct's average variance extracted (AVE) is larger than its correlations with other constructs (Chin, 1998). The first assessment of discriminant validity is to examine the indicators' loadings with respect to all construct correlations. As shown in table 4.3, all the items are well loaded on their constructs much higher than the cross loadings on other construct which satisfies the first assessment of the measurement model's discriminant validity (Chin, 1998). 
Table 4.3. Factor Loadings and Cross-Loadings

\begin{tabular}{l|l|l|l|l|l|l|l}
\hline & QSP & $\mathbf{T}$ & $\mathbf{R S}$ & $\mathbf{R}$ & $\mathbf{A}$ & $\mathbf{E}$ & $\mathbf{L}$ \\
\hline QSP1 & $\mathbf{0 . 9 3 6}$ & 0.2103 & 0.239 & 0.226 & 0.214 & 0.175 & 0.457 \\
\hline QSP2 & $\mathbf{0 . 7 5 7}$ & 0.113 & 0.295 & 0.137 & 0.169 & 0.234 & 0.335 \\
\hline QSP3 & $\mathbf{0 . 9 2 1}$ & 0.220 & 0.225 & 0.239 & 0.206 & 0.398 & 0.506 \\
\hline QSP4 & $\mathbf{0 . 9 2 9}$ & 0.237 & 0.460 & 0.258 & 0.199 & 0.303 & 0.430 \\
\hline T1 & 0.112 & $\mathbf{0 . 6 1 0}$ & 0.112 & 0.391 & 0.205 & 0.301 & 0.038 \\
\hline T2 & 0.262 & $\mathbf{0 . 9 2 5}$ & 0.225 & 0.437 & 0.193 & 0.321 & 0.258 \\
\hline T3 & 0.100 & $\mathbf{0 . 7 6 6}$ & 0.225 & 0.287 & 0.204 & 0.312 & 0.090 \\
\hline T4 & 0.067 & $\mathbf{0 . 6 6 8}$ & 0.254 & 0.409 & 0.261 & 0.421 & 0.098 \\
\hline RS1 & 0.024 & 0.226 & $\mathbf{0 . 5 1 6 3}$ & 0.170 & 0.183 & 0.312 & 0.116 \\
\hline RS2 & 0.030 & 0.229 & $\mathbf{0 . 8 6 5}$ & 0.204 & 0.218 & 0.253 & 0.047 \\
\hline RS3 & 0.038 & 0.226 & $\mathbf{0 . 8 7 1}$ & 0.243 & 0.130 & 0.227 & 0.140 \\
\hline RS4 & 0.070 & 0.199 & $\mathbf{0 . 9 1 4}$ & 0.192 & 0.125 & 0.229 & 0.128 \\
\hline R1 & 0.265 & 0.366 & 0.234 & $\mathbf{0 . 9 6 2}$ & 0.189 & 0.330 & 0.258 \\
\hline R2 & 0.096 & 0.225 & 0.204 & $\mathbf{0 . 6 8 4}$ & 0.209 & 0.288 & 0.056 \\
\hline R3 & 0.258 & 0.114 & 0.201 & $\mathbf{0 . 9 5 5}$ & 0.163 & 0.285 & 0.234 \\
\hline R4 & 0.032 & 0.368 & 0.220 & $\mathbf{0 . 6 4 5}$ & 0.180 & 0.245 & 0.016 \\
\hline R5 & 0.032 & 0.468 & 0.220 & $\mathbf{0 . 6 4 6}$ & 0.180 & 0.245 & 0.016 \\
\hline A1 & 0.184 & 0.260 & 0.180 & 0.220 & $\mathbf{0 . 8 2 9}$ & 0.182 & 0.199 \\
\hline A2 & 0.185 & 0.166 & 0.116 & 0.116 & $\mathbf{0 . 8 4 5}$ & 0.238 & 0.194 \\
\hline A3 & 0.182 & 0.266 & 0.182 & 0.224 & $\mathbf{0 . 8 3 2}$ & 0.164 & 0.191 \\
\hline A4 & 0.185 & 0.173 & 0.132 & 0.124 & $\mathbf{0 . 8 4 9}$ & 0.249 & 0.197 \\
\hline E1 & 0.020 & 0.262 & 0.219 & 0.180 & 0.186 & $\mathbf{0 . 6 0 9}$ & 0.059 \\
\hline E2 & 0.020 & 0.339 & 0.213 & 0.253 & 0.226 & $\mathbf{0 . 6 3 8}$ & 0.053 \\
\hline E3 & 0.057 & 0.378 & 0.251 & 0.309 & 0.162 & $\mathbf{0 . 7 9 3}$ & 0.083 \\
\hline E4 & 0.101 & 0.314 & 0.189 & 0.244 & 0.241 & $\mathbf{0 . 8 8 9}$ & 0.107 \\
\hline E5 & 0.063 & 0.298 & 0.286 & 0.285 & 0.144 & $\mathbf{0 . 7 1 5}$ & 0.055 \\
\hline L1 & 0.162 & 0.162 & 0.162 & 0.184 & 0.248 & 0.124 & $\mathbf{0 . 9 4 2}$ \\
\hline L2 & 0.180 & 0.180 & -0.038 & 0.163 & 0.052 & 0.020 & $\mathbf{0 . 5 8 6}$ \\
\hline L3 & 0.163 & 0.163 & 0.200 & 0.189 & 0.247 & 0.116 & $\mathbf{0 . 9 3 2}$ \\
\hline L4 & 0.186 & 0.186 & -0.019 & 0.175 & 0.078 & 0.002 & $\mathbf{0 . 5 8 8}$ \\
\hline L5 & 0.165 & 0.165 & 0.156 & 0.204 & 0.246 & 0.112 & $\mathbf{0 . 9 3 8}$ \\
\hline & & & & & & & \\
\hline
\end{tabular}

Second, the square root of the AVE of each construct was compared with the correlation between that construct and the other constructs. As shown in table 4.4, the square root of the AVEs exceeds the highest correlation between that construct and the other constructs, providing another support of discriminant validity (Chin 1998; Fornell\&Larcker, 1981) of the constructs in this study.

Table 4.4. Discriminant Validity Assessment

\begin{tabular}{l|l|l|l|l|l|l|l}
\hline & QSP & T & RS & R & A & E & L \\
\hline QSP & $\mathbf{0 . 9 0 0}$ & & & & & & \\
\hline $\mathbf{T}$ & 0.221 & $\mathbf{0 . 7 5 3}$ & & & & & \\
\hline $\mathbf{R S}$ & 0.258 & 0.257 & $\mathbf{0 . 8 0 6}$ & & & & \\
\hline $\mathbf{R}$ & 0.243 & 0.207 & 0.243 & $\mathbf{0 . 7 9 7}$ & & & \\
\hline $\mathbf{A}$ & 0.120 & 0.258 & 0.182 & 0.204 & $\mathbf{0 . 8 3 8}$ & & \\
\hline $\mathbf{E}$ & 0.289 & 0.410 & 0.293 & 0.336 & 0.249 & $\mathbf{0 . 7 4 0}$ & \\
\hline $\mathbf{L}$ & 0.552 & 0.202 & 0.136 & 0.222 & 0.233 & 0.289 & $\mathbf{0 . 8 1 6}$ \\
\hline
\end{tabular}

*Square root of the AVE on the diagonal.

4.4 Predictive Relevance $\left(Q^{2}\right)$

Predictive relevance $\left(\mathrm{Q}^{2}\right)$ shows the predictive capability of the model (Fornell\& Cha 1994). 
$\mathrm{Q}^{2}>0$ implies the model has predictive relevance whereas $\mathrm{Q}^{2}<0$ means that the model lacks predictive relevance. The blindfolding procedure is used to assess the cross-validated redundancy of constructs (Henseler et al., 2009). This study has got a $Q^{2}$ value of 0.213 for Perceived Quality Service Provision which is greater than zero and indicates the predictive relevance of the model (Henseler et al., 2009).

\subsection{Coefficient of Determination $\left(R^{2}\right)$}

The coefficient of determination $\left(\mathrm{R}^{2}\right)$ value implies how much the independent variables can influence the dependent variable. In this study, the $\mathrm{R}^{2}$ is 0.543 that means that the dependent variable is influenced by the independent variables by 54.30 percent. So the six independent variables namely, tangibility, reliability, responsiveness, assurance, empathy and logistic support considered in this study have substantial effect on the perceived quality service provision while the remaking 45.75 percent might be influenced by other factors which have not been considered in this study.

\subsection{Structural Model Assessment for Hypotheses Testing}

Having assessed the measurement model for reliability and validity, the PLS structural model was run for testing the hypotheses of the study. Table 4.5 shows the findings of the structural model for hypotheses testing. A hypothesis can be accepted if it is significant at 5 percent $(\mathrm{p}<0.05)$ level or if the $t$ statistics is higher than 1.96 (Hair et al., 2014).

Table 4.5. The Structural Estimates.

\begin{tabular}{c|c|c|c|c|c|c}
\hline $\begin{array}{c}\text { Hypothesiz } \\
\text { ed Path }\end{array}$ & Hypotheses & $\begin{array}{c}\text { Path } \\
\text { Coefficient }\end{array}$ & $\begin{array}{c}\text { Standard } \\
\text { Error }\end{array}$ & $\begin{array}{c}\text { T-Val } \\
\text { ue }\end{array}$ & $\begin{array}{c}\text { P-Val } \\
\text { ue }\end{array}$ & $\begin{array}{c}\text { Level of } \\
\text { Significance }\end{array}$ \\
\hline T ->QSP & H1 & 0.201 & 0.041 & 2.163 & 0.015 & $* * *$ \\
\hline RS ->QSP & H & 0.219 & 0.064 & 3.749 & 0.000 & $* * *$ \\
\hline R ->QSP & H3 & 0.108 & 0.066 & 2.198 & 0.014 & $* *$ \\
\hline A ->QSP & H4 & 0.054 & 0.050 & 1.075 & 0.141 & - \\
\hline E ->QSP & H5 & 0.114 & 0.067 & 2.206 & 0.014 & $* *$ \\
\hline L ->QSP & H6 & 0.308 & 0.036 & 3.492 & 0.000 & $* *$ \\
\hline
\end{tabular}

Note: $* * \mathrm{P}<0.05 ; * * * \mathrm{P}<0.01$.

Hypothesis one is supported as the table 4.5 depicts that the path coefficient value is 0.201 and the $t$ statistics is $2.163(\mathrm{P}<0.05)$ that indicates 5 percent significance level. Therefore it is accepted that Tangibility is positively and significantly correlated with quality service provision. The findings of present study prove that Responsiveness is positively and significantly correlated with perceived quality service provision. Here the variable has a path coefficient value of 0.219 and this value is significant at 1 percent $(t, 3.749 ; \mathrm{P},<.01)$ level. So Hypothesis two is accepted. The findings of this hypothesis testing show that Reliability is significantly and positively correlated with quality service provision. The path coefficient for this variable is 0.108 and the $t$ statistic is $2.198(\mathrm{P}<0.05)$. Therefore, hypothesis three is accepted. From the table 4.5, it is seen that assurance value has a path coefficient value of 0.054 and the corresponding t statistics is 1.075 which is not significant $(p>0.05)$. Therefore, hypothesis 4 which posits that Assurance positively influences quality service provision is not supported. Hypothesis five is supported as the path coefficient has got a positive value of 
0.114 and the corresponding $\mathrm{t}$ statistics is 2.206 which is significant at 5 percent level $(\mathrm{p}<0.05)$. So, Empathy is an important predictor of quality service provision. Hypothesis six also supported as the path coefficient value is 0.308 with a positive sign and the corresponding $t$ value is 3.492 which is significant at 1 percent level $(\mathrm{p}<0.01)$. So it is proved through this empirical study that logistic support positively influences quality service provision.

\section{Discussion and Conclusion}

The statistical findings of this study reveal that tangibility, responsiveness, reliability, empathy dimensions and logistic supports are the significant factors influencing the perceived service quality services of the local government. Among them, responsiveness was found to the most significant followed by logistic support, empathy, reliability and tangibles. Reliability is an important dimension of SERVQUAL model and the findings of this study also prove that reliability is positively and significantly correlated with the perceived quality services of local government towards the slum dwellers. This finding is consistent with those of (Parasuraman, 1988; Berry \& Parasuraman, 1991; Leelapongprasut, 2005; Ahamad, 2010; Chang \& Chen, 2011; Wanjiru, 2013; but inconsistent with the findings of Munhurrun et al., (2010) who found in their study that reliability is not an important dimension for perceived quality services. However, Maniam et al., (2014) found that reliability dimension is a significant factor that might make the local government's services more effective. It is due to the fact that reliability is the ability to provide the promised service dependably and accurately (Parasuraman et al, 1985). It also comprises of promises and doing things right. The slum dwellers expect flawless services from the local government; and if they get reliable services, they will be happy with the local government. Since most of the previous studies found positive association between reliability dimension and perceived quality services, local government should focus on the reliability of their services towards the slum dwellers.

This study found that responsiveness dimension of service quality is positively and significantly correlated with the perceived quality services of local government towards the slum dwellers. It indicates that responsiveness dimension can increase the perceived service quality of local government towards the slum dwellers. This finding is consistent with those of Hollis\& Victor, 2004; Ahamad, 2009; Wanjiru, 2013; who gave emphasis on the responsiveness dimension of service quality to increase organizational performance. In the context of local government services, Maniam et al (2014) also found that responsiveness dimension of SRVQUAL model is a vital factor for the effectiveness of local government services. The slum dwellers expect prompt services from the local government. Once they are in trouble, the local government should come up with solution as soon as possible. In the context of local government's services, responsiveness is measured as how much time it takes to attend the citizens' requests, questions, complaints and also their problems. For providing better services to the slum dwellers, local government should recover the problems quickly, otherwise, they will lose their trustworthiness. Therefore, the DCC should deliberately work to ensure responsiveness so that perceived service quality can be improved a lot. The present study's findings reveal that tangibility dimension of service quality is positively and 
significantly correlated with perceived quality service of local government. It indicates that tangibility is an important issue to provide better services to the slum dwellers. This finding is consistent with those of Atalik, Arslan \&Ahamad, 2009; Munhurrun, Bhiwajee \& Naidoo, 2010; Wanjiru, 2013; who found that tangibility dimension of service quality is a significant factor for increasing the service quality of an organization. The slum dwellers make inferences about the services quality on the basis of the buildings, the physically out and others that surround the services environment of the local government because these can have a significant impact on their affective responses. This study found that assurance dimension of service quality is insignificantly correlated with the perceived service quality of local government. It indicates that assurance dimension of service quality is not an important predictor of perceived service quality of local government. This study found that empathy dimension of service quality is positively and significantly correlated with perceived service quality of local government. It indicates that assurance dimension of service quality has positive influence on perceived service quality of local government. This finding is consistent with those of Munhurrun, Bhiwajee \& Naidoo, 2010; Wanjiru, 2013; who found that empathy dimension is a significant factor to increase the service quality of an organization. Therefore, the empathy dimension of service quality should be managed in a way so that best services can be provided to the slum dwellers. Finally, the findings of this study reveal that logistic support plays very significant role in enhancing the service quality of DCC towards the slum dwellers. It indicates Dhaka City Corporation should have enough logistic support that encompasses the logistic services, materiel, and transportation required to support the continuous development work in the slums. Proper logistic support might enable the workforce to provide better services.

The outcome of this research work has enriched the existing body of knowledge in the field of local government's service quality. The policy makers, local government and other related stakeholders might find this study as an essential tool in designing, developing and implementing their activities directed to the slum dwellers. Moreover, reliable and valid scales have been developed for assessing the perceived service quality of local government and this instrument will be a valuable help for the future researchers of this field. Findings of this study will allow local government all over the world to take into consideration the importance of the pertinent factors that might exhort profound impact on enhancing perceived services quality. Hence, this study opens the door for researchers to further perform research in this area to come up with new ideas to accelerate the living standard of slum dwellers. Moreover, the findings of this research work will provide directions for the improvement of knowledge in this area and it will add some insights in the horizon of knowledge in the existing body of academic literatures.

\section{References}

Akther, M. S., Islam, I., \& Hasan, M. U. (2009). Evaluation of municipal services in selected wards of Dhaka City Corporation: citizen's perspective. Theoretical and Empirical Researches in Urban Management Special Number 1S/April 2009: URBAN ISSUES IN ASIA Bank Institute, 2007. 
Alam, H. (2005). Mosquito menace on as DCC fails. New Age. Dhaka.

Arasli, H., Katircioglu, S. T., \& Mehtap, S. S. (2005). A comparison of service quality in thebanking industry: some evidence from Turkish and Greek-speaking areas in Cyprus. International Journal ofbank marketing, 23(7), 508-526. https://doi.org/10.1108/02652320510629881

Atalik, O., \& Arslan, M. (2009). A Study to Determine the Effects of Customer Value on Customer Loyalty inAirline Companies operating: Case of Turkish Air Travelers", International Journal of Business and Management, 4(6), 154-162.

Bagozzi, R. P., \& Yi, Y. (1988). On the evaluation of structural equation models. Journal of the Academy of Marketing Science, 16(1), 74-94. https://doi.org/10.1007/BF02723327

Brysland, A., \& Curry, A. (2001). Service improvements in public services using SERVQUAL. Managing Service Quality, 11(6), 389-401. https://doi.org/10.1108/09604520110410601

Cavana, R. Y., Corbett, L. M., \& Lo, Y. L. (2007). Developing Zones of Tolerance for Managing Passenger RailServices Quality, International Journal of Quality and Reliability Management, 24(1), 7-31. https://doi.org/10.1108/02656710710720303

Chang, H. H., \& Wang, H. W. (2011). Themoderating effect of customer perceived value on online shopping behavior. Online Information Review, 35(3), 333-359. https://doi.org/10.1108/14684521111151414

Chin, W. W. (1998). The partial least squares approach to structural equation modeling. In: Marcoulides, G. A., editor. Modern Methods for Business Research. Mahwah, New Jersey: Laurence Erlbaum Associates, 295-336.

Duarte, P., \& Raposo, M. (2010). A PLS model to study brand preference: An application to the mobile phone market. In: Esposito Vinzi, V., Chin, W.W., Henseler, J., Wang, H., editors. Handbook of Partial Least Squares. New York: Springer Berlin Heidelberg, 449-485. https://doi.org/10.1007/978-3-540-32827-8_21

Fornell, C., \& Cha, J. (1993). Partial Least Squares (PLS), Unpublished working paper. Ann Arbor: University of Michigan Business School.

Fornell, C., \& Larcker, D. (1981). Structural equation models with unobservable and measurement error. Journal of Marketing Research, 18(1), 39-50. https://doi.org/10.2307/3151312

Fornell, C., \& Wernerfelt, B. (1987). Defensive Marketing Strategy by Customer Complaint Management: A Theoretical Analysis, Journal of Marketing Research, (24), November 1987, 337-46. https://doi.org/10.2307/3151381

Hair, J. F., Hult, G. T. M., Ringle, C. M., \& Sarstedt, M. (2014). A primer on partial least squares structural equation modeling (PLS-SEM).Thousand Oaks, CA: SAGE Publications.

Hair, J. F., Sarstedt, M., Ringle, C. M., \& Mena, J. A. (2012). An assessment of the use of 
partial least squares structural equation modeling in marketing research. Journal of the Academy of Marketing Science, 40(3), 414-433. https://doi.org/10.1007/s11747-011-0261-6

Henseler, J., Ringle, C. M., \& Sinkovics, R. R. (2009). The use of Partial Least Squares path modeling in international marketing. Advances in International Marketing, 20, 277-319. https://doi.org/10.1108/S1474-7979(2009)0000020014

Hossain, M. I., \& Wagatsuma, Y., et al. (2004). Analysis of some Socio-demographic Factors Related to DF/DHF Outbreak in Dhaka City. Dengue Bulletin 24.

Ishikawa, S. (1996). Diversity in Television Programming: Comparative Analysis of Five Countries. In S. Ishikawa (Ed.), Quality Assessment of Television. Luton: University of Luton Press.

Jabnoun, N., \& Al-Tamimi, H. A. H. (2003). Measuring perceived service quality at UAE commercial banks. International Journal of Quality \& Reliability Management, 20(4), 458-472. https://doi.org/10.1108/02656710310468614

Jarosław, 1. (2011). The effectiveness of crisis management's logistics support in local governments. Advanced Logistic Systems, 7(1), 57-64.

Julia, B. (2015). Supporting water sanitation and hygiene services for life Capacity support to local Governments. BRIEFING NOTE March 2015 (Reprinted). Building blocks for sustainability series.

Kabir, M. R. (2016). Municipal Solid Waste Management System: A Study on Dhaka North and South City Corporations. Journal of Bangladesh Institute of Planners ISSN 2075-9363, Vol. 8, 2015 (Printed in December 2016), 35-48, () Bangladesh Institute of Planners.

Kim, M., Park, M., \& Jeong, D. (2004). The Effects of Customer Satisfaction and Switching Barrier on CustomerLoyalty in Korean Mobile Telecommunication Services, Telecommunications Policy, 28, 145-159. https://doi.org/10.1016/j.telpol.2003.12.003

Łodzi tom X zeszyt, 8, 9-22.

Luck, T. M. (2008). The World's Dirtiest Cities. Forbes. New York.

Mohammad, S. H. S., Atiq, U. Z., Tahmina, A., \& Fahmid, A. (2017). Transforming Urban Dichotomies and Challenges of South Asian Megacities: Rethinking Sustainable Growth of Dhaka, Bangladesh. Urban Sci, 1(31). https://doi.org/10.3390/urbansci1040031

Nowak, E. (2009). Logistyka i zarządzanie logistyczne w sytuacjach kryzysowych SWSPiZ w

Parasuraman, A., Zeithaml, V. A., \& Berry, L. L. (1985). A conceptual model of service quality and its implications for future research. the Journal of Marketing, 41-50. https://doi.org/10.2307/1251430

Parasuraman, A., Zeithaml, V. A., \& Berry, L. L. (1985). A conceptual Model of Service Quality and its implications for Future Research, Journal of Marketing, 49, 41 -50. https://doi.org/10.2307/1251430 
Parasuraman, A., Zeithaml, V. A., \& Berry, L. L. (1988). SERVQUAL: A Multiple Item Scale for Measuring Customer Perceptions of Service Quality, Journal of Retailing, 64, 12 - 40.

Pereira, M. J., Claver, C. E., Molina, A. J. F., \& Tarí, J. J. Quality management, environmental management and firm performance:direct and mediating effects in the hotel industry, Journal of Cleaner Production, $\quad 37, \quad 82-92$. https://doi.org/10.1016/j.jclepro.2012.06.010

Qureshi, I., \& Compeau, D. (2009). Assessingbetween-group differences in informationsystems research: a comparison of covarianceandcomponent-based sem. MIS Quarterly, 33(1), 197-214. https://doi.org/10.2307/20650285

Ramseook, M. P., Lukea, B. S. D., \& Naidoo, P. (2010). Service quality in the public service. International Journal of Management and Marketing Research, 3(1), 37-50.

Ringle, C., Wende, S., \& Will, A. (2005). SmartPLS 2.O(Beta), Hamburg.

Rivera, T. P. (2008). Why do Patterns ofEnvironmental Response Differ?AStakeholders` Pressure Approach. StrategicManagement Journal, 29(11), 1225-1240. https://doi.org/10.1002/smj.711

Rodríguez, P. G., Burguete, J. L. V., Vaughan, R., \& Edwards, J. (2009). Quality dimensions in the public sector: municipal services and citizen's perception. Journal of InternationalReview on Public and Nonprofit Marketing, 6(1), 75-90. https://doi.org/10.1007/s12208-009-0030-0

Sandhu, H. S., \& Bala, N. (2011). Customers' Perception towards Service Quality of Life Insurance Corporation of India - A Factor Analytic Approach, International Journal of Business and Social Science, 2(18), 219-231.

Selvakumar, J. J. (2016). Impact of service quality on customer satisfaction in public sector and private sector banks. Purushartha: A Journal of Management Ethics and Spirituality, $8(1)$.

Siddiqy, M. R. (2017). Urban environment and major challenges in sustainable development: Experience from Dhaka City in Bangladesh. South East Asia Journal of Public Health, 7(1), 12-16. https://doi.org/10.3329/seajph.v7i1.34673

Suraiya, Y., \& Md Imranur, R. A. (2017). Review of Solid Waste Management Practice in Dhaka City, Bangladesh. International Journal of Environmental Protection and Policy, 5(2), 19-25. https://doi.org/10.11648/j.ijepp.20170502.11

Tahir, I. M., \& Abu Bakar, N. M. (2007). Service quality gap and customers' satisfaction of commercial banks inMalaysia. International Review of Business Research Papers, 3(4), $327-336$.

Van Ryzin, G. G. (2004). The measurement of overall citizen satisfaction. Public Performance and Management Review, 27(3), 9-28.

Wanjiru, N. S. (2013). Service quality and performance of paid television services: the case 
study of zuku company limited. A research project submitted in partial fulfillment of the requirements for the award of the degree of master of business administration (MBA) school of business university of Nairobi.

Wisniewski, M. (2001). Using SERVQUAL to assess customer satisfaction with public sector services, Managing Service Quality, 11(6), 350-388. https://doi.org/10.1108/EUM0000000006279

Zeithaml, V. A., Parasuraman, A., \& Berry, L. L. (1990). Delivering quality service: Balancing customer perceptions and expectations. Simon and Schuster.

\section{Copyright Disclaimer}

Copyright for this article is retained by the author(s), with first publication rights granted to the journal.

This is an open-access article distributed under the terms and conditions of the Creative Commons Attribution license (http://creativecommons.org/licenses/by/4.0/). 